\title{
Developing an Independent Curriculum: Village Development Project as an Equalization of Thesis
}

\author{
https://doi.org/10.3991/ijet.v16i07.21225 \\ Joan Hesti Gita Purwasih, Elya Kurniawati, Nur Hadi \\ Universitas Negeri Malang, Malang, Indonesia \\ Indah Wahyu Puji Utami ( $\left.{ }^{\varpi}\right)$ \\ Nanyang Technological University, Nanyang Ave, Singapore \\ nie19.iwpude.ntu.edu.sg
}

\begin{abstract}
The university curriculum is always required to be able to answer future challenges. On the other hand, universities have the responsibility for producing quality human resources in nation-building. Evaluation and development of the curriculum are some of the best ways to improve the quality of education. Therefore, every policymaker needs to make this effort so that these two responsibilities can be fulfilled. In this development research, the researcher designed an independent curriculum to actually be implemented. As a result, there are two important aspects emphasized on at the core of the curriculum renewal being developed. The first is to strengthen student capabilities contextually through collaborative projects. The second is the involvement of partners in order to provide real benefits to the community. In this curriculum design, village development is a superior program that is carried out to integrate these two aspects. This effort is made because the village is one of groups vulnerable to the problem of poverty. The implementation design of these two aspects was finally developed successfully, and a village development project was offered to students as an equivalent thesis. This policy is a way considered effective and accepted positively by various parties, including government, partners, and also students.
\end{abstract}

Keywords-Curriculum, independent, village, thesis

\section{Introduction}

Educated unemployment rate has been increased over years globally. Such condition occurs due to some factors, among others: the effect of industrial revolution 4.0 wave, migration due to inadequate job opportunity with reasonable wage, and wish to improve life wellbeing [1][2]. The further effect of such phenomenon is that most developing countries instead loses their own educated workers. This is called "brain drain"[3]. Unfortunately, Indonesia has potential risk of encountering this. Amid the opening of more new universities, the adequate absorption of workers instead decreases [4]. Educated (college graduate) unemployment rate increases over years. This condition is specifically due to the large gap between education field and work realm, between theory and 
practice. Some factors triggering it are: 1) the graduates' knowledge incompatible to the demand or the standard expected by the employers, (2) incompatibility of expected income to graduate status, (3) limited job opportunity, (4) changing socio-economic structure and global political dynamic resulting in the shift of competency qualification the relationship between graduates, colleges, and job opportunity provider is often complex. It is highly dependent on the universities' or colleges' ability of producing the quality graduates as expected by the job market [6].

In this regard, the curriculum evaluation and revitalization are crucial to improve human resource quality in many countries [7][8][9]. Indonesian should deal with similar condition by revitalizing its curriculum focusing on improving hard skill and soft skill, developing vocational program, and certifying specialties very desirable [10]. Education is not enough for students' self-development. Involving students in college research and service can equip them to obtain an experience with the complexity of real work as well. Such attempts have been taken in Germany. Involving universities students in work realm during their education period is the best way to revise the curriculum in order to enhance the students' self-quality. Germany is one of states to apply apprenticeship system to their students. This effort has made $80 \%$ of their graduates integrating successfully into labor market. Work based learning is one of effective ways to develop students' hard-skill and soft-skill [11]. Five universities in Australia do similarly; they apply this program in the last year of education program. The result shows that validation of graduates' ability of developing skill corresponding to the curriculum [12].

In 2020, such attempt has also been taken by Indonesian government. Indonesian government launched a new curriculum policy for higher education level called "Merdeka Belajar: Kampus Merdeka (MBKM) (Freedom to Learn: Independent Campus) (thereafter called MBKM policy)" [13]. This curriculum is generally called curriculum 2020. This policy gives the students a right to participate in education outside their study program for three semesters. It means that students can get an opportunity of taking course or other learning experience to support their transdisciplinary specialty. There are eight programs that can be developed by each of study programs to accommodate it: 1) student exchange, 2) apprenticeship/internship, 3) teaching assistance in educational unit, 4) research, 5) humanity project, 6) entrepreneurship, 7) independent study/project, and 8) building village/thematic Student Community Service [14]. Indonesian government, through Ministry of Education and Culture, grants stimulant fund for the eight programs. Each of colleges or universities can submit ten proposals from each of study programs to be selected nationally. The elected proposal will develop the intact design of proposed program accordingly.

Curriculum reform has also been made by all study programs in all colleges and universities nationally in Indonesia. This policy is required to standardize and to ensure that the national objective of education can be integrated into students' need in the future [15]. A variety of strategies have been taken in many study programs to reform their curriculum and to accommodate the MBKM policy all at once. In the future, each of study programs is allowed to admit students from other disciplines so that the program provided should take such condition into account. This measure should have been long initiated by government. It is because the higher education curriculum has been 
the foundation for the development of skilled labors so that connectivity built inside should involve stakeholders in various fields [16].

In response to the current policy of MBKM, Prodi S1 Pendidikan Sosiologi (Department of Sociological Education) of Universitas Negeri Malang raises a theme "building village to fulfill the students' right to learn outside study program". This theme is raised not only to give the students the field experience in order to be adaptive, creative, and innovative, but also to contribute to realizing a sustainable village development in 2030. It is due to the condition of villages in East Java that mostly still needs serious attention from the government. Data of Regional Medium-Term Development Plan (RPJMD) of East Java in 2019-2024 shows that there are six basic social issues in rural areas in East Java that should be addressed immediately: 1) poor accessibility and quality of education service, 2) poor accessibility and quality of healthcare service, 3) poor accessibility and quality of people housing and settlement area service, 4) poor public tranquility, orderliness, and protection, and 5) poor accessibility and quality of social service [17]. Therefore, as the only Department of Sociology Education in East Java, this program is committed to bring the moral responsibility into reality.

A university should affect positively at least the areas surrounding through innovative programs. The positive effect is expected to be experienced not only by community but also by students. This out-of-campus experience facilitates them to get recognition of 20 credit hours, including the recognition of final project conversion. Therefore, this research is conducted to elaborate strategy and design resulting from the development of village building program integrated into curriculum.

\section{$2 \quad$ Method}

The development of village building program is integrated into the curriculum of study program. The authors adapts Ralph W. Tyler's model stating that students are active individuals and their activities are encouraged by one goal [18]. The procedure of Tyler's curriculum development model is shown in figure 1 [19].

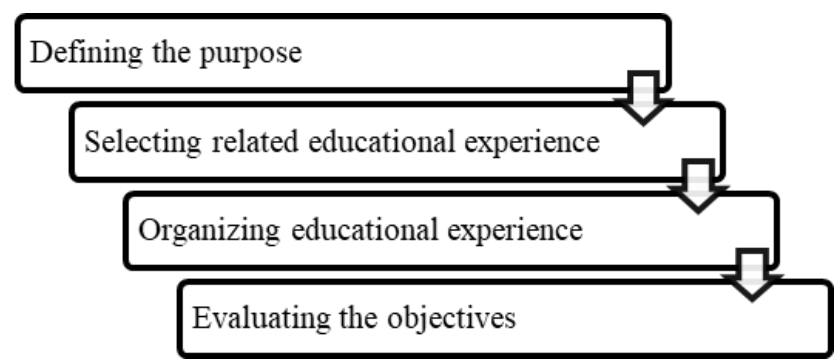

Fig. 1. Tyler's Curriculum Development Model

The authors used this Tyler's model as it is relevant to be used in many disciplines or subjects and education levels. In addition, its logical sequence makes this model easy to be evaluated [20]. Although this output focuses on the feasibility of program, its position is inseparable from the curriculum. Therefore, this model is used to revise the 
design of existing curriculum. In goal setting stage, the authors reflected and analyzed the need through self-evaluation and graduate evaluation methods. Then, the author mapped the relevant learning experience resulting from the evaluation on the presentation structure of department course. Subsequently, this process was integrated into the villages or partners' need in the field. The organization of experience was conducted by the department by designing the field practice implementation procedure. The output is put into the guidelines accessible to students. The product of program development is trialed using two models: construct evaluation by expert and students polling.

\section{$3 \quad$ Result and Discussion}

\subsection{Program's goal}

This "Sociology Building Village" Program is intended to improve the students' capability of facing the future challenges contextually. Nevertheless, there are broader achievable objectives, i.e., to establish and to develop cooperation with new partners to implement the development of scholarship in order to benefit the community.

To achieve the goals or objectives, education, research, and service are integrated into a holistic program. This program is, of course, taken by students through formulating the competency gain as the initial measure. It can be accomplished through internal and external reflections. Thereafter, evaluation is conducted to see its compatibility to the profile of graduates in the curriculum of 2020.

Table 1. Program Competency Gain

\begin{tabular}{|c|l|}
\hline No. & \multicolumn{1}{|c|}{ Program Competency Gain } \\
\hline 1. & $\begin{array}{l}\text { Ability of designing empowerment contextually and targeting appropriately the local community/in- } \\
\text { stitution existing in rural areas. }\end{array}$ \\
\hline 2. & $\begin{array}{l}\text { Ability of applying empowerment program along with many parties to promote the local commu- } \\
\text { nity/institution existing in rural areas. }\end{array}$ \\
\hline 3. & $\begin{array}{l}\text { Ability of developing expedient design/product/prototype/model to promote the local community/in- } \\
\text { stitution existing in rural areas. }\end{array}$ \\
\hline 4. & Ability of writing original scientific work recognized nationally or internationally \\
\hline 5. & $\begin{array}{l}\text { Ability of showing off leadership, communicative, creative, innovative, and social care spirits con- } \\
\text { textually to promote the local community/institution existing in rural areas. }\end{array}$ \\
\hline
\end{tabular}

\subsection{Learning experience and its position in the curriculum}

Having analyzed the goal achievements, the authors conducted a study on course presentation and partners' need analysis. Firstly, the authors analyzed the existing curriculum of 2020 in the department (study program) through the composition of course as shown in figure 2 . 
Table 2. Composition of Course

\begin{tabular}{|c|l|c|}
\hline No & \multicolumn{1}{|c|}{ Course Group } & $\begin{array}{c}\text { Number of } \\
\text { Credit Units }\end{array}$ \\
\hline 1. & Basic Course of Character Development (MDPK) (Compulsory) & 12 \\
\hline 2. & $\begin{array}{l}\text { Scholarship and Specialty Course (compulsory), consisting of 98 credit units in- } \\
\text { cluding: }\end{array}$ & \\
\hline & Pedagogic Basic Course (MDKP) & 8 \\
\hline & Subject Course (MKBS) & 82 \\
\hline & Introduction of School Field (PLP) & 4 \\
\hline & KKN (Student Community Service) & 4 \\
\hline 3. & $\begin{array}{l}\text { Concentration and Self Development Course (this course is optional and 38 } \\
\text { credit units of which are offered for transdisciplinary course }\end{array}$ & 54 \\
\hline \multicolumn{1}{|c|}{ TOTAL Credit Unit Presentation } \\
\hline \multicolumn{2}{|c|}{ Requirement of Credit Units for Graduates } & 164 \\
\hline
\end{tabular}

Furthermore, the authors analyzed the distribution and sequence in seven semesters by sorting the credit units mapped. It is conducted because this program needs the equalization of 2 credit units as recommended by the government.

Table 3. Course Structure

\begin{tabular}{|l|l|l|c|}
\hline \multirow{2}{*}{ Semester } & \multicolumn{2}{|c|}{ Number of Credit Units Presented } & \multirow{2}{*}{ Credit Units to be taken } \\
\cline { 2 - 4 } & \multicolumn{1}{|c|}{ Compulsory (MDPK and $\mathbf{M K K})$} & \multicolumn{1}{c|}{ Optional $(\mathbf{M P P D})$} & 10 \\
\hline VII & 10 credit units & & 20 \\
\hline VI & & 20 credit units & 24 \\
\hline V & 14 credit units & 10 credit units & 24 \\
\hline IV & 22 credit units & 2 credit units & 24 \\
\hline III & 24 credit units & & 22 \\
\hline II & 20 credit units & 2 credit units & 22 \\
\hline I & 20 credit units & 2 credit units & \\
\hline
\end{tabular}

The structure shows that the department has had adequate course distribution and sequence, i.e., the students can actually take this program in the $6^{\text {th }}$ and $7^{\text {th }}$ semesters. In addition, in those semesters the students have been ready to get into the field because they have taken most of courses. Their experience with lecturing can be utilized in the field, thus bridging the gap between theory and practice.

Furthermore, the result of need analysis with some partners reveals the topics that can be developed in the field. The partners in this program are 11 villages, 1 school, and 1 educational organization that have had MoU with the Department. The topics presented in table 1 are the example and can be developed according to the actual field condition. 
Table 4. Topics compatible to partners' need

\begin{tabular}{|l|l|}
\hline \multicolumn{2}{|c|}{ Educational Topics } \\
\hline 1. & $\begin{array}{l}\text { Assistance in rural schools to reinforce teachers' and students' competency in improving the } \\
\text { quality of learning. }\end{array}$ \\
\hline 2. & $\begin{array}{l}\text { The development of design and alternative models implementing long distance learning in rural } \\
\text { areas. }\end{array}$ \\
\hline 3. & $\begin{array}{l}\text { Facilitation to build Community Learning Activity Center/Learning Home/ Training Center in } \\
\text { rural areas. }\end{array}$ \\
\hline 4. & Facilitation and advocacy for migrant worker families in rural areas. \\
\hline \multicolumn{2}{|c|}{ Economics } \\
\hline 1. & Facilitation to build village potency through Micro-, Small-, and Medium Enterprises. \\
\hline 2. & Reinforcement in the management of Village-Owned Enterprises. \\
\hline 3. & Local Potency-Based Product Management. \\
\hline \multicolumn{2}{|c|}{ Tourism } \\
\hline 1. & Tourism Potency Development based on local wisdom. \\
\hline 2. & Facilitation of tourist object optimization \\
\hline 3. & $\begin{array}{l}\text { Facilitation and empowerment of Tourism-Conscious Group (Pokdarwis), Forest Village Com- } \\
\text { munity Institution or Karang Taruna }\end{array}$ \\
\hline \multicolumn{2}{|c|}{ Environment } \\
\hline 1. & Processing waste into usable product in rural areas. \\
\hline 2. & Sustainable Tourism Development \\
\hline 3. & Education for critical land rehabilitation. \\
\hline \multicolumn{2}{|c}{ Culture } \\
\hline 1. & Facilitation in the attempt of preserving local culture in art communities in rural areas. \\
\hline 2. & Facilitation in initiating both regional- and national-scale cultural art events. \\
\hline 3. & Facilitation to promote local culture in the attempt of entering into international market. \\
\hline
\end{tabular}

\subsection{The organization of learning experience}

The "Sociology Building Village" Program was then organized to enable its implementation to be applied by the students in the field. The author wrote a guidance book containing the detailed procedure as the students' handbook in the field. This program organization is shown in figure 2 .

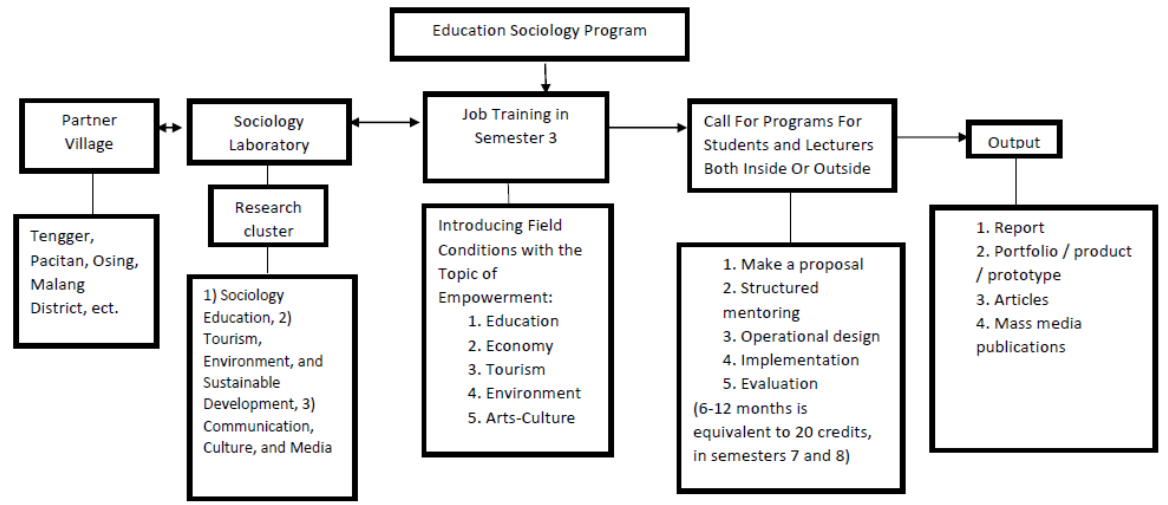

Fig. 2. The organization of learning experience 
The assessment method used in this program is hybrid. The hybrid assessment model is used because in principle this program leads the students to do the field project. At this level, the project applied leads to Action Research to solve the real problem in the field. It means that, in addition to final gain (output), process becomes the important factor to be considered in assessment. In addition, the projects carried on are likely varying. Nevertheless, whatever the type of project, the assessment form presented should be relevant and flexible, so that hybrid model is chosen in score conversion. The assessment is conducted with weights of $40 \%$ for planning process, $30 \%$ for implementation, and $30 \%$ for gain or output.

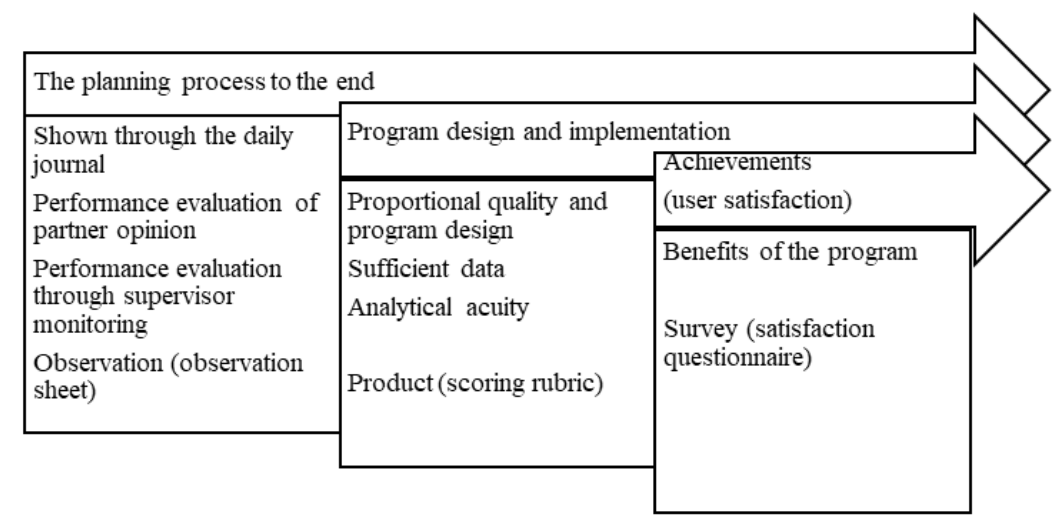

Fig. 3. Program Assessment Model

\subsection{Evaluation of program design feasibility}

The program is evaluated by considering expert and potential users' opinions. The expert involved in this program one of Head of Sociology Education Department in other university. The result of evaluation indicates that curriculum design, program design, and evaluation technique have been very compatible to MBKM program mandated by the government. Additionally, the program is presented systematically and adequately to support the students' capability.

Then, the author socialized and distributed the questionnaires to students to assess the program feasibility and their preparedness for attending the program offered. The result of survey on 79 student's of 2020 cohort reveals the opinions as shown in table 5. 
Table 5. Result of Design feasibility survey

\begin{tabular}{|c|l|l|}
\hline No. & \multicolumn{1}{|c|}{ Question Item } & \multicolumn{1}{|c|}{ Result } \\
\hline 1. & Clear and adequate objective of program & $24 \%$ strongly agree and $75.9 \%$ agree \\
\hline 2. & Clear program implementation procedure & $\begin{array}{l}\text { l2.25\% strongly agree, } 75.95 \% \text { agree, and 2.90\% disa- } \\
\text { gree. }\end{array}$ \\
\hline 3. & Adequate credit unit equalization & $\begin{array}{l}16.46 \% \text { strongly agree, } 79.75 \% \text { agree, and } 1.45 \% \text { disa- } \\
\text { gree. }\end{array}$ \\
\hline 4. & Interesting program topics & $27.85 \%$ strongly agree, 70.89 agree. \\
\hline 5. & Clear and adequate score conversion & $11.39 \%$ strongly agree, $83.54 \%$ agree, $4.35 \%$ disagree. \\
\hline 6. & $\begin{array}{l}\text { Supporting the reinforcement of students' } \\
\text { competency in work realm }\end{array}$ & $29.11 \%$ strongly agree, and 69.62\% disagree. \\
\hline 7. & Benefiting the institution and the community & $34.18 \%$ strongly agree, $64.56 \%$ agree, $1.45 \%$ disagree. \\
\hline 8. & Helping accelerate the graduation & $21.52 \%$ strongly agree, $69.62 \%$ agree, $7.25 \%$ disagree. \\
\hline 9. & $\begin{array}{l}\text { The program is compatible to the formulation } \\
\text { of graduate profile }\end{array}$ & $17.72 \%$ strongly agree, $78.48 \%$ agree, 2.90\% disagree. \\
\hline 10. & $\begin{array}{l}\text { The program is implemented in adequate se- } \\
\text { mester and time allocation, thereby minimiz- } \\
\text { ing the scheduling conflict }\end{array}$ & $13.92 \%$ strongly agree, $79.75 \%$ agree, $5.80 \%$ disagree. \\
\hline
\end{tabular}

Table 6. Result of survey on students' preparedness

\begin{tabular}{|c|l|l|}
\hline No. & \multicolumn{1}{|c|}{ Question Item } & \multicolumn{1}{|c|}{ Result } \\
\hline 1. & $\begin{array}{l}\text { I am interested in taking MBKM Program of Sociological Educa- } \\
\text { tion Building Village. }\end{array}$ & $\begin{array}{l}17.72 \% \text { strongly agree, 69.62 } \\
\text { agree, 12.66\% disagree }\end{array}$ \\
\hline 2. & $\begin{array}{l}\text { I am ready for attending this program after having taken the com- } \\
\text { pulsory courses presentation in my department. }\end{array}$ & $\begin{array}{l}8.86 \% \text { strongly agree, } 73.42 \% \\
\text { agree, 15.19\% disagree }\end{array}$ \\
\hline 3. & $\begin{array}{l}\text { I am ready for cooperating with students from other departments to } \\
\text { attend this program. }\end{array}$ & $\begin{array}{l}21.52 \text { strongly agree, 69.62\% } \\
\text { agreed, 7.59\% disagree }\end{array}$ \\
\hline 4. & $\begin{array}{l}\text { I think what I have gotten in lecturing period will make me ready } \\
\text { for getting into the community. }\end{array}$ & $\begin{array}{l}21.52 \% \text { strongly agree, 63.29\% } \\
\text { agree, 13.92\% disagree. }\end{array}$ \\
\hline 5. & $\begin{array}{l}\text { I think having attended study for some semesters in my department } \\
\text { I will be able to develop innovative programs in this program. }\end{array}$ & $\begin{array}{l}17.72 \% \text { strongly disagree, } \\
68.35 \% \text { agree, 12.66\% disagree. }\end{array}$ \\
\hline
\end{tabular}

Considering the result of evaluation of program feasibility, it can be inferred that this "Sociological Education Building Village" program achieves the very feasible criteria to be integrated into the Curriculum of 2020. This field development with research model integrated into village community service is adapted from the skill plus project that has evidently improved their competitiveness in labor market [21]. It is expected to solve the problem of labor feasibility so far becoming the homework to high education in general.

Higher education should open access to cooperation through open space based on research and education not only at national but also at international levels. This attempt will activate the function of institution through the management of faculty, lecturers and students creating a variety of innovation and common goodness [22]. Unfortunately, in this program, partner and cooperative project constructed have not reached the international partner level yet. It becomes our homework in the future. However, this program dares sufficiently to start with local scale level, village. In addition, the involvement of partner, external evaluator, and students in this program organizing process is conducted to actually achieve the common advantage. The curriculum designed 
collaboratively can be an appropriate means to address the community's need effectively in the present and the future [23].

In the future, this program development not only stops in the development of implementation design in the field. Technology-based content and interactive lecturing media are needed to actually educate the students on the real condition of village and city [24]. In addition, the integration of field and online learning models should be conducted to maximize monitoring during field practice. Project-based blended learning model can be inserted into the curriculum to address the problem [25]. This supporting component will be the focus of authors' attention in further researches.

\section{Conclusion}

Higher education and its graduates should be future-ready . Development process should be conducted continuously and sustainably. Nevertheless, the development does not always run as planned and targeted. Social problems related to the poor qualities of human resource, social-cultural gap, and poverty are today the issues still unsolved by governments, particularly in rural areas. Therefore, village development should get special attention from the stakeholders, including academicians. Development should not rest on the government. Through collaborative empowerment program along with academicia, community can build its regions comprehensively and independently.

\section{$5 \quad$ References}

[1] Y. Feng, D. Lagakos, and J. E. Rauch, "Unemployment and Development," National bureau of economic research, 2018.

[2] O. Stark and C. S. Fan, "The Prospect of Migration, Sticky Wages, and 'Educated Unemployment,"” Rev. Int. Econ., vol. 19, no. 2, pp. 277-287, 2011. https://doi.org/10.1111/ j.1467-9396.2011.00946.x

[3] C. S. Fan and O. Stark, "International migration and 'educated unemployment," J. Dev. Econ., vol. 83, no. 1, pp. 76-87, 2007.

[4] T. Handayani, "Relevansi Lulusan Perguruan Tinggi Di Indonesia Dengan Kebutuhan Tenaga Kerja Di Era Global," J. Kependud. Indones., vol. 10, no. 1, p. 53, 2015. https://doi.org/10.14203/iki.v10i1.57

[5] Badan Pusat Statistik, "Keadaan Ketenagakerjan Indonesia Agustus 2019." Badan Pusat Statistik, Jakarta, 2019, [Online]. Available: https://www.bps.go.id/pressrelease/2019/11/ 05/1565/agustus-2019--tingkat-pengangguran-terbuka--tpt--sebesar-5-28-persen.html. https://doi.org/10.31219/osf.io/nqt4f

[6] S. M. Murage and S. O. Onyuma, "Analysis of Financial Performance of Income Generating Activities in Public Higher Learning Institutions: Experience from Egerton University, Kenya," Res. J. Financ. AccountingOnline), 2015.

[7] Z. Hanapi and M. S. Nordin, "Unemployment among Malaysia Graduates: Graduates'Attributes, Lecturers' Competency and Quality of Education," Procedia - Soc. Behav. Sci., vol. 112, pp. 1056-1063, 2014. https://doi.org/10.1016/j.sbspro.2014.01.1269

[8] P. Lewis and J. Heyes, “The changing face of youth employment in Europe," Econ. Ind. Democr., p. 0143831X17720017, 2017. 
[9] I. Clark, N. Nae, and M. Arimoto, "Education for Sustainable Development and the "Whole Person' Curriculum in Japan,” in Oxford Research Encyclopedia of Education, 2020. https://doi.org/10.1093/acrefore/9780190264093.013.935

[10] F. Wijayanti and I. Turgel, "Industrial Revolution 4.0: Is Indonesia Labor Market Ready or Not?," in XIV International Conference «Russian Regions in the Focus of Changes» Special Edition, 2019, pp. 18-27, [Online]. Available: https://www.esd-conference.com/upload/ book_of_proceedings/Book_of_Proceedings_Ekaterinburg_2019_Online.pdf\#page=23

[11] D. Kintu, "An Exploration of Strategies for Facilitating Graduates' Transition to the World of Work: A Case of Technical, Vocational Education and Training Graduates in Uganda," Int. J. Vocat. Educ. Train. Res., 2019. https://doi.org/10.11648/j.ijvetr.20190501.11

[12] D. Wood and C. Bilsborow, “'I am not a person with a creative mind': Facilitating creativity in the undergraduate curriculum through a design-based research approach," Electron. J. eLearning, 2014.

[13] Kemendikbud, "Mendikbud Luncurkan Empat Kebijakan Merdeka Belajar: Kampus Merdeka," Kementerian Pendidikan dan Kebudayaan, 2020. https://doi.org/10.31219/ osf.io/67rcq

[14] Direktur Jenderal Pendidikan Tinggi, "Buku Panduan Merdeka Belajar - Kampus Merdeka," Direktorat Jenderal Pendidik. Tinggi Kementeri. Pendidik. dan Kebud., 2020. https://doi. org/10.31219/osf.io/ujmte

[15] R. W. Tyler, Basic Principles of Curriculum and Instruction. 2013.

[16] A. Bell, “A Connected Curriculum for Higher Education,” High. Educ. Res. Dev., 2020, doi: 10.1080/07294360.2019.1663026.

[17] Pemerintah Provinsi Jawa Timur, "Rencana Pembangunan Jangka Menengah Daerah (RPJMD) Prov. Jatim 2019 - 2024,” Surabaya, 2019. [Online]. Available: http://jatimprov.go.id/ppid/uploads/berkasppid/RPJMD Prov. Jatim 2019 - 2024.pdf. https://doi.org/ $\underline{10.31227 / \mathrm{osf} .10 / \mathrm{aehfu}}$

[18] G. F. Madaus and D. L. Stufflebeam, "New Dimensions in Curriculum Development," in Educational Evaluation: Classic Works of Ralph W. Tyler, 1989. https://doi.org/ $\underline{\text { 10.1007/978-94-009-2679-0_7 }}$

[19] T. Mehmood Bhuttah, C. Xiaoduan, H. Ullah, and S. Javed, "Analysis of Curriculum Development Stages from the Perspective of Tyler, Taba and Wheeler," 2019.

[20] V. Cruickshank, "Considering Tyler's Curriculum Model in Health and Physical Education,” J. Educ. Educ. Dev., 2018. https://doi.org/10.22555/joeed.v5i1.1443

[21] P. Knight and M. Yorke, Learning, Curriculum and Employability in Higher Education. 2003.

[22] D. Fung, A Connected Curriculum for Higher Education. 2017.

[23] K. P. Uchiyama and J. L. Radin, "Curriculum Mapping in Higher Education: A Vehicle for Collaboration,” Innov. High. Educ., 2009. https://doi.org/10.1007/s10755-008-9078-8

[24] X. Wang, Z. Hao, S. Luo, and M. Ren, "A teaching model of Urban and Rural Planning Curriculum Integrating Virtual simulation Technology,” Int. J. Emerg. Technol. Learn., vol. 13, no. 6, pp. 149-162, 2018. https://doi.org/10.3991/ijet.v13i06.8584

[25] W. Yu and X. Du, "Implementation of a Blended Learning Model in Content- Based EFL Curriculum,” Int. J. Emerg. Technol. Learn., vol. 14, no. 5, pp. 188-199, 2019. https:// doi.org/10.3991/ijet.v14i05.8546 


\section{Authors}

Joan Hesti Gita Purwasih is a lecturer in Sociology department in Universitas Negeri Malang, Indonesia. Email: joan.hesti.fis@um.ac.id

Elya Kurniawati is a lecturer in Sociology department in Universitas Negeri Malang. Email: elya.kurniawati.fis@um.ac.id

Nur Hadi is a lecturer in Sociology department in Universitas Negeri Malang. Email: nur.hadifis@um.ac.id

Indah Wahyu Puji Utami a doctoral student in Humanities and Social Studies, National Institute of Education, Nanyang Technological University Email: nie19.iwpu @e.ntu.edu.sg

Article submitted 2021-01-07. Resubmitted 2021-02-23. Final acceptance 2021-02-24. Final version published as submitted by the authors. 